\title{
Occurrence and Physiological Breakdown of Self-incompatibility in Easter Cactus
}

\author{
Thomas H. Boyle', Fabian D. Menalled ${ }^{2}$, and Maureen C. O'Leary ${ }^{3}$ \\ Department of Plant and Soil Sciences, French Hall, University of Massachusetts, Amherst, MA 01003
}

Additional index words. electron microscopy, electrophoresis, fruit set, growth substances, isozymes, ornamental plants, pollen, Rhipsalidopsis gaertneri, Rhipsalidopsis xgraeseri

\begin{abstract}
The existence of self-incompatibility (SI) was demonstrated in 'Britton' and 'Rose' Easter cactus (Rhipsalidopsis). In a full diallel cross among five clones, 18 out of 20 outcrosses resulted in $68 \%$ to $100 \%$ fruit set, whereas reciprocal crosses between two of the clones and all five self-pollinations failed to set fruit. Pollen tube growth was greatly inhibited in styles of selfed pistils, but there was no evidence of pollen tube inhibition in compatibly crossed pistils. Easter cactus exhibited characteristics typically found in sporophytic SI systems (trinucleate pollen, papillate stigmas, and scant stigmatic exudate) together with those associated with gametophytic SI systems (stylar inhibition of pollen tube growth and absence of reciprocal differences in outcrosses). Additional experiments were performed to determine the effects of bud pollinations, growth regulators (BA, GA, and NAAm), and high temperatures (0- to 48-h exposure at 40C) on the SI response. Heat treatments were more effective than either bud pollinations or growth regulators in overcoming SI, and yielded an average of 7.2 viable seeds per treated flower when plants were incubated for $12 \mathrm{~h}$ at $40 \mathrm{C}$ and selfed immediately after incubation. Isozyme analysis of the $S_{0}$ parent and putative $S_{1}$ progeny confirmed that selfing had occurred following heat treatments. Using $S_{1}$ progeny in breeding programs may extend the flower color range and lead to a greater diversity in other plant characteristics than presently exists in cultivated germplasm. Chemical names used: $N$-(phenylmethyl)-1H-purin-6-amine [benzyladenine (BA)], gibberellic acid $\left(G_{3}\right)$, and $\alpha$-naphthaleneacetamide (NAAm).
\end{abstract}

The genus Rhipsalidopsis, commonly known as Easter cactus, encompasses two species of epiphytic or lithophytic shrubs that are native to southeastern Brazil (Liberty Hyde Bailey Hortorium, 1976). Plants are composed of a series of discrete, flattened or angular stem segments (phylloclades). Rhipsalidopsis rosea (Lagerheim) Britt. \& Rose is a compact plant with phylloclades 2.5 to $3.8 \mathrm{~cm}$ long and rose-pink flowers 2.5 to $3.8 \mathrm{~cm}$ wide (Moran, 1953). Rhipsalidopsis gaertneri (Regel) Moran is larger than $R$. rosea and has phylloclades 3.8 to $7.6 \mathrm{~cm}$ long and bright red flowers 6.4 to $8.9 \mathrm{~cm}$ wide (Moran, 1953). Cultivars of Easter cactus include clonal selections of $R$. rosea, R. gaertneri, and their interspecific hybrids [ $R$. × graeseri (Werdermann) Moran]. Commercial interest in Easter cactus is increasing in North America due to its potential as a flowering pot plant (Boyle and Stimart, 1989).

Self-incompatibility (SI) is a genetically controlled mechanism that prevents fertilization in fertile hermaphroditic plants when they are selfed or crossed to another plant with an identical incompatibility phenotype (de Nettancourt, 1977). Major reviews on the distribution of SI in angiosperms do not document any cases of SI for the Cactaceae (Brewbaker, 1957, 1959; East, 1940; Fryxell, 1957). However, several reports suggest that SI is widespread in the Cactaceae (Breckenridge and Miller, 1982; Ganders, 1976; Ross, 1981; Taylor, 1976). Ganders (1976) and Taylor (1976), observing a lack of fruit set following selfing, concluded that SI was present in $R$. gaertneri and $R$. rosea, respectively. In a preliminary investigation, we self-pollinated several cultivars of Easter cactus but failed to obtain fruit set, thus corroborating Gander's (1976) and Taylor's (1976) results (T.H. Boyle, unpublished data).

Increased variability in Easter cactus would be beneficial for

Received for publication 17 Nov. 1993. Accepted for publication 11 Feb. 1994. Publication no. 3123 of the Massachusetts Agricultural Experiment Station. The cost of publishing this paper was defrayed in part by the payment of page charges. Under postal regulations, this paper therefore must be hereby marked advertisement solely to indicate this fact.

${ }^{1}$ Associate professor. To whom reprint requests should be addressed.

${ }^{2}$ Graduate research assistant, Dept. of Forestry and Wildlife Management.

${ }^{3}$ Graduate research assistant. greater diversity in plant morphology and flower color. It would therefore be desirable to recover $S_{1}$ progeny to obtain plants homozygous for recessive genes affecting plant habit and flower color. The purpose of this study was to 1) identify factor(s) preventing fruit set following self-pollination and 2) determine the effects of growth substances, heat treatments, and timing of pollination on yields of self-seed.

\section{Materials and Methods}

General procedures. Plants were propagated and grown in glasshouses at the University of Massachusetts, Amherst (lat. 42 ${ }^{\circ}$ $22.5^{\prime} \mathrm{N}$ ). Glasshouse temperatures were maintained at $16 \mathrm{C}$ minimum and 30C maximum during experiments. Shading compound (Kool Ray, Continental Products Co., Euclid, Ohio) was applied to the glass to maintain photosynthetic photon flux (PPF) below $\approx 650$ $\mu \mathrm{mol} \cdot \mathrm{m}^{-2} \cdot \mathrm{s}^{-1}$. Flowering was attained by controlling temperature and photoperiod (Boyle, 1991).

Emasculation consisted of removing the corolla and anthers with forceps followed by washing of the stigmatic lobes with deionized water to dislodge adhering material. For most experiments, mature flower buds were emasculated 1 or 2 days before anthesis, but open flowers and flower buds at various stages of development were emasculated in Expt. 4. Pollination was performed by rubbing recently dehisced anthers on the stigmatic lobes. Each bud/flower was pollinated once using pollen collected from two or more flowers. Except where noted, pollination occurred $24 \mathrm{~h}$ after emasculation.

Fruits were harvested at 90 days after pollination (DAP) in Expts. 4 and 6, and at $\approx 160$ DAP in Expts. 1 and 5. Results of Expts. 4 and 6 indicate that seed maturation was completed by 90 DAP. For Expt. 1, seeds were germinated in 0.23-liter plastic pots filled with a soilless medium [1 sand : 1 sphagnum peat (by volume)]. Pots were kept in a glasshouse maintained at $18 \pm 1.5 \mathrm{C} / 20 \pm 2 \mathrm{C}$ (night/day). For Expts. 4, 5, and 6, seeds were germinated in covered petri dishes on top of two circles of Whatman no. 1 filter paper that were saturated with deionized water. Petri dishes were placed in incubators set at $20 \pm 1 \mathrm{C}$ with $52 \pm 8 \mu \mathrm{mol} \cdot \mathrm{s}^{-1} \cdot \mathrm{m}^{-2} \mathrm{PPF}$ 
(12 h daily) provided by cool-white fluorescent lamps (Zimmer, 1980). The numbers of germinated seed were determined at 21 days after sowing. A seed was considered germinated upon emergence of the radicle.

Effects of selfing and outcrossing on fruit and seed set (Expt. 1). Five cultivars of Easter cactus ( $R$. gaertneri 'Crimson Giant', and $R$. ×graeseri 'Andre', 'Evita', 'Purple Pride', and 'Red Pride') were crossed in a full diallel composed of 10 pairs of reciprocal crosses and five self-pollinations. Pollinations were performed in Apr. 1990, using 25 flowers for each self or cross. At 90 DAP, fruit remaining on the plants were counted and percent fruit set was calculated for each cross. Fruits were harvested at 160 DAP and seeds were germinated as described previously. Confirmation of crosses between cultivars was based on morphological comparisons between the 2-year-old seedlings and their parents.

Effect of selfing and outcrossing on pollen germination and pollen tube growth (Expt. 2). Emasculated flowers of 'Crimson Giant' were either selfed or crossed with compatible pollen ('Evita'). Pistils were removed from plants at $1,3,5$, or 7 DAP, and fixed in 3 ethanol : 1 glacial acetic acid (v/v) for $\geq 24 \mathrm{~h}$. In order to observe pollen tube growth in the ovary, the ovary wall was cut away from two sides of each pistil to produce a median longitudinal section ( $\approx 2 \mathrm{~mm}$ thick) with the stigma and style remaining attached and intact. Pistils were softened for $24 \mathrm{~h}$ in $4 \mathrm{~N} \mathrm{NaOH}$, stained with $0.1 \%$ (w/v) decolorized aniline blue in $0.1 \mathrm{M} \mathrm{K}_{3} \mathrm{PO}_{4}$ (Martin, 1959), and examined with an epifluorescence microscope (Carl Zeiss, Thornwood, N.Y.) equipped for ultraviolet/violet light excitation. The study consisted of nine treatments (two pollen sources $\times$ four harvest periods plus an unpollinated control). A minimum of 10 pistils was observed per treatment.

In a second study, nonemasculated flowers of 'Crimson Giant' and 'Evita' were self-pollinated on the day of anthesis. Flowers were collected when petals were fully senesced ( 9 to 12 DAP), and pistils were fixed, sectioned, and stained as described previously. Ten pistils were observed for each cultivar. All pollinations were performed in Apr. 1993.

Morphology of the stigmatic surface and mature pollen (Expt. 3). 'Crimson Giant' styles were collected at anthesis, fixed in $2.5 \%$ (w/v) glutaraldehyde in $0.1 \mathrm{M}$ cacodylate buffer at $4 \mathrm{C}$ for $2 \mathrm{~h}$, washed twice with $0.1 \mathrm{M}$ cacodylate buffer, postfixed with $1 \%$ (w/ v) aqueous $\mathrm{OsO}_{4}$ for $4 \mathrm{~h}$, and left overnight in $0.1 \mathrm{~m}$ cacodylate buffer. Fixed styles were dehydrated through an ethanol series, dried over $\mathrm{CO}_{2}$ in a Polaron critical point dryer (Polaron Instruments, Hatfield, Pa.), mounted on aluminum stubs with silver paint, and coated with gold/palladium (300 to $400 \AA$ thickness). Four stigmas were examined using a scanning electron microscope (model JSM-255; JEOL USA, Peabody, Mass.).

'Crimson Giant' pollen was collected at anthesis, fixed in 3 ethanol : 1 glacial acetic acid (v/v) for $\geq 12 \mathrm{~h}$, and stained with 0.50 $\mu \mathrm{g} \cdot \mathrm{ml}^{-1}$ mithramycin A (Sigma, St. Louis) in $20 \%(\mathrm{w} / \mathrm{v})$ sucrose (Coleman and Goff, 1985). Pollen was examined by epifluorescence microscopy, as described in Expt. 2. A minimum of 1000 pollen grains were observed. Styles and pollen were collected in Apr. 1993.

Effects of pollen source and stage of floral development at pollination on fruit and seed set (Expt. 4). The length of intact flower buds was measured on several 'Crimson Giant' plants. Flower buds were then grouped by length into six classes, using a $0.5-\mathrm{cm}$ class interval and a lower limit of $1 \mathrm{~cm}$. Open flowers were placed in a separate class, yielding a total of seven classes. Buds and open flowers were tagged to indicate their respective classes, emasculated, and pollinated $24 \mathrm{~h}$ later using self or cross-compatible pollen. The experiment consisted of 14 treatments (seven classes $\times$ two pollen sources). A minimum of 20 buds/flowers were pollinated per treatment. All pollinations were performed in Nov. 1991.

Fruit were counted and harvested at 90 DAP, and seeds were cultured as described previously. Percent fruit set, number of seeds per fruit, percent seed germination, and number of viable seeds per treated flower were calculated for each class of buds and open flowers. Number of viable seeds per treated flower was calculated for each treatment by dividing the number of germinating seed by the number of flowers pollinated.

Concurrent with the above study, 10 flower buds with an initial length of $0.86 \pm 0.81 \mathrm{~cm}$ (mean $\pm \mathrm{SE}$ ) were measured daily until anthesis. Average bud length was plotted against time, and the graph was used to estimate the number of days to anthesis for each class of buds.

Effect of growth regulators on fruit and seed set following selfing (Expt. 5). Three growth regulators (BA, GA 3 , and NAAm) were mixed individually in hot $(\approx 140 \mathrm{C})$ lanolin at concentrations of 0.1 and $1.0 \%(\mathrm{w} / \mathrm{v})$. The mixtures were stored at $2 \mathrm{C}$ and warmed to room temperature (20 to 25C) before application (Emsweller, 1954). Flower buds $>3.5 \mathrm{~cm}$ in length were emasculated and pollinated 24 to $48 \mathrm{~h}$ later. A v-shaped nick $(\approx 0.5 \mathrm{~cm}$ long) was made on the ovary wall immediately after pollination, and 0.1 to $0.2 \mathrm{ml}$ of a growth regulator mixture or lanolin alone (control) was applied to the nick. The experiment consisted of seven treatments (three growth regulators $\times$ two concentrations plus a lanolin control) with 25 flowers per treatment. Multiple flowers were pollinated on each plant, but only one growth regulator was applied per plant to avoid confounding effects. Pollinations were performed in Oct. 1986.

The numbers of set fruit were counted at 90 DAP and percent fruit set was calculated for each treatment. Fruits were harvested at $\approx 160$ DAP and seeds were cultured as described previously. Number of seeds per fruit, percent seed germination, and number of viable seeds per treated flower were calculated for each treatment.

Effects of heat treatments, timing of pollination, and pollen source on fruit and seed set (Expt. 6). Flower buds $>3.5 \mathrm{~cm}$ in length were emasculated on several plants, and $24 \mathrm{~h}$ later the plants were transferred to a controlled-environment chamber (model I-35LVL; Percival Mfg., Boone, Iowa) providing $40 \pm 1 \mathrm{C}$ and a 12-h photoperiod $\left(52 \pm 8 \mu \mathrm{mol} \cdot \mathrm{s}^{-1} \cdot \mathrm{m}^{-2} \mathrm{PPF}\right)$ from cool-white fluorescent lamps. Plants were incubated in the chamber for 6,12 , 24 , or 48 h. For each incubation period, plants were pollinated immediately before incubation, or $0,12,24$, or $36 \mathrm{~h}$ after incubation, using either self or cross-compatible pollen. Control plants received ambient conditions in the glasshouse $[18 \pm 1.5 \mathrm{C} / 20 \pm 2 \mathrm{C}$ (night/day) and 25C maximum temperature] and were pollinated $24 \mathrm{~h}$ after emasculation. The experiment consisted of 18 treatments, and a minimum of 18 flowers were pollinated per treatment. Only one pollen source (self or cross-compatible) was used per plant. Plants with selfed flowers were separated from plants with cross-pollinated flowers by a minimum distance of $3 \mathrm{~m}$. All plants were maintained in a glasshouse section isolated from other flowering Rhipsalidopsis cultivars. Compatible pollen was collected from plants kept in a separate greenhouse. The experiment was performed during Nov. 1991.

Fruits were harvested at 90 DAP, and seeds were cultured as described previously. Percent fruit set, number of seeds per fruit, percent seed germination, and number of viable seeds per treated flower were calculated for each treatment.

Genetic analysis of $S_{1}$ progeny (Expt. 7). Seedlings obtained from self-pollinations in Expt. 6 were transplanted into 0.07-liter 
plastic cells filled with a soilless medium and were grown in a glasshouse maintained at $18 \pm 1.5 \mathrm{C} / 20 \pm 2 \mathrm{C}$ (night/day). Seventy-three seedlings were randomly selected from the population of $\approx 125$ plants, and one phylloclade was collected from each seedling and the $S_{0}$ parent ('Crimson Giant') in July 1993. About $8 \mathrm{mg}$ of tissue was sampled from each phylloclade and placed in a microcentrifuge tube containing $0.1 \mathrm{ml}$ of cold $(\approx 1 \mathrm{C})$ extraction buffer [0.05 м Tris-HCl buffer (pH 7.5), 0.014 м 2-mercaptoethanol, and 5\% sucrose (w/v) (Wendel and Weeden, 1989)]. Samples were thoroughly macerated and centrifuged $(10,000 \mathrm{rpm})$ for $10 \mathrm{~min}$ at $4 \mathrm{C}$. About $0.02 \mathrm{ml}$ of the supernatant was placed in a microcentrifuge tube containing $0.005 \mathrm{ml}$ of cold $(\approx 1 \mathrm{C})$ sample loading buffer composed of $50 \%(\mathrm{v} / \mathrm{v})$ glycerol and $0.1 \%(\mathrm{w} / \mathrm{v})$ bromophenol blue. Native proteins were separated by polyacrylamide gel electrophoresis (PAGE) using a Mini-Protean II cell (Bio-Rad Laboratories, Hercules, Calif.). Gels were assayed for phosphoglucomutase (PGM, E.C. 5.4.2.2) and aspartate aminotransferase (AAT, E.C. 2.6.1.1) [= glutamate oxaloacetate transaminase (GOT)]. Phosphoglucomutase was resolved on gels consisting of a $4 \%$ (w/ v) stacking gel $[0.125 \mathrm{M}$ Tris- $\mathrm{HCl}$ buffer $(\mathrm{pH} 6.8)]$ and a $7.5 \%(\mathrm{w} /$ v) running gel [0.375 м Tris-HCl buffer ( $\mathrm{pH} 8.8)]$ (Hames, 1981). Aspartate aminotransferase was resolved on $7.5 \%(\mathrm{w} / \mathrm{v})$ single-percentage gels prepared with a $0.375 \mathrm{M}$ Tris- $\mathrm{HCl}$ buffer ( $\mathrm{pH}$ 8.8). The electrode buffer for PGM and AAT was $0.025 \mathrm{M}$ Tris- $\mathrm{HCl}$ and $0.2 \mathrm{M}$ glycine $(\mathrm{pH} 8.3)$. Electrophoresis was performed at 3 to $4 \mathrm{C}$ under constant voltage $(200 \mathrm{~V})$ for $\approx 0.75 \mathrm{~h}$. Gels were stained for AAT and PGM activity using the protocols of Wendel and Weeden (1989). For each enzyme, loci were numbered sequentially, with 1 denoting the most anodally migrating locus. Alleles at individual loci were designated by letters assigned sequentially from the anode. Isozyme segregation was evaluated by chi-square analysis.

\section{Results and Discussion}

Expt. 1. Cross-pollinations between 'Andre' and 'Crimson Giant' and all self-pollinations failed to set fruit (Table 1). With the exception of 'Andre' $x$ 'Crimson Giant', crosses between different clones yielded $68 \%$ to $100 \%$ fruit set (Table 1). Fruits derived from outcrosses contained $\approx 75$ to 150 viable seeds each (data not presented). Approximately 30 progeny from each outcross were evaluated at flowering (Table 1). The progeny differed from their putative parents in phylloclade size and form, flower size, and flower color (T.H. Boyle, unpublished data). These observations indicate that the progeny were $\mathrm{F}_{1} \mathrm{~s}$, i.e., derived from sexual fusion between gametes, and that the parental clones were not agamospermous (apomictic).

Expt. 2. By 1 DAP, pollen had germinated and pollen tubes had penetrated the stigmatic surface on selfed and outcrossed pistils
(Fig. $1 \mathrm{~A}$ and B). Callose plugs were clearly visible in pollen tubes on selfed and outcrossed pistils (Fig. 1 A and D). At 1 DAP, a few pollen tubes extended halfway down the style on selfed pistils (Fig. 1C), but numerous pollen tubes were present halfway down the style on outcrossed pistils (Fig. 1D). At 3 DAP, few (6) pollen tubes had reached the base of the style on selfed pistils, whereas large numbers (usually >50) of pollen tubes had traversed the style and entered the ovary cavity on outcrossed pistils (Fig. $1 \mathrm{E}$ and F). The responses at 5 and 7 DAP were similar to those at 3 DAP, except that greater numbers of pollen tubes $(>100)$ had penetrated the ovary cavity in outcrossed pistils. At 7 DAP, few pollen tubes $(\leq 6)$ were observed at the base of the style on selfed pistils (Fig. $1 \mathrm{E})$.

Selfed flowers of 'Evita' and 'Crimson Giant' that were collected at senescence exhibited an abundance of germinated pollen grains and normal pollen tube penetration of the stigmatic surface. However, numbers of pollen tubes decreased dramatically between the stigma and base of the style. Attrition of pollen tubes was most apparent in the middle of the style, but inhibition of pollen tube growth was also observed in the lower third of the style. Hence, inhibition of incompatible pollen tubes was not confined to a particular stylar region. The numbers of pollen tubes observed at the base of the style were $3.8 \pm 0.6$ and $2.0 \pm 0.7$ for 'Evita' and 'Crimson Giant', respectively.

Results of Expts. 1 and 2 clearly demonstrate that SI occurs in Easter cactus, thus corroborating the results of Ganders (1976) and Taylor (1976). Although the majority of crosses between the five clones resulted in high yields of seed-bearing fruit, selfing resulted in stylar inhibition of pollen tube growth and failure to set fruit. 'Andre' and 'Crimson Giant' were reciprocally cross-incompatible but reciprocally cross-compatible with 'Evita', 'Purple Pride', and 'Red Pride', and these responses indicate that the former two clones have identical incompatibility phenotypes. Thus, Easter cactus displays the salient feature of SI in angiosperms: the hindrance or prevention of fertilization when an SI identity factor in the pollen grain or pollen tube matches a similar SI identity factor in the pistil (Ascher, 1975).

Expt. 3. The stigmatic surface was densely covered with elongate papillae (Fig. 2 ). The papillae were $\approx 30 \mu \mathrm{m}$ in diameter, $\approx 150$ $\mu \mathrm{m}$ in length, and rounded at the apices. Pollen grains collected at anthesis were $\approx 65 \mu \mathrm{m}$ in diameter and trinucleate, with each grain containing one large vegetative cell and two smaller sperm cells (Fig. 3). Trinucleate pollen has been also reported for Pereskia amapola Weber [P. sacharosa Griseb. (Liberty Hyde Bailey Hortorium, 1976)], a primitive, leaf-bearing Cactaceae species (Neumann, 1935).

Brewbaker (1957) reported that the type of SI system in homomorphic angiosperms was correlated with pollen cytology and the site of inhibition. In species displaying gametophytic

Table 1. Percent fruit set following intercrossing and selfing of five Easter cactus cultivars and number of progeny evaluated from each cross (Expt. 1).

\begin{tabular}{|c|c|c|c|c|c|}
\hline \multirow[b]{3}{*}{ Female parent } & \multicolumn{5}{|c|}{ Percent fruit set (number of progeny evaluated) } \\
\hline & \multicolumn{5}{|c|}{ Male parent } \\
\hline & Andre & Crimson Giant & Evita & Purple Pride & Red Pride \\
\hline Andre & $0^{\mathrm{z}}(0)$ & $0(0)$ & $100(36)$ & $100(34)$ & $100(23)$ \\
\hline Crimson Giant & $0(0)$ & $0(0)$ & $100(34)$ & $96(36)$ & $80(31)$ \\
\hline Evita & $80(33)$ & $92(35)$ & $0(0)$ & $68(30)$ & $72(34)$ \\
\hline Purple Pride & $84(0)$ & $76(26)$ & $100(24)$ & $0(0)$ & $84(28)$ \\
\hline Red Pride & $100(30)$ & $100(32)$ & $100(31)$ & $100(28)$ & $0(0)$ \\
\hline
\end{tabular}



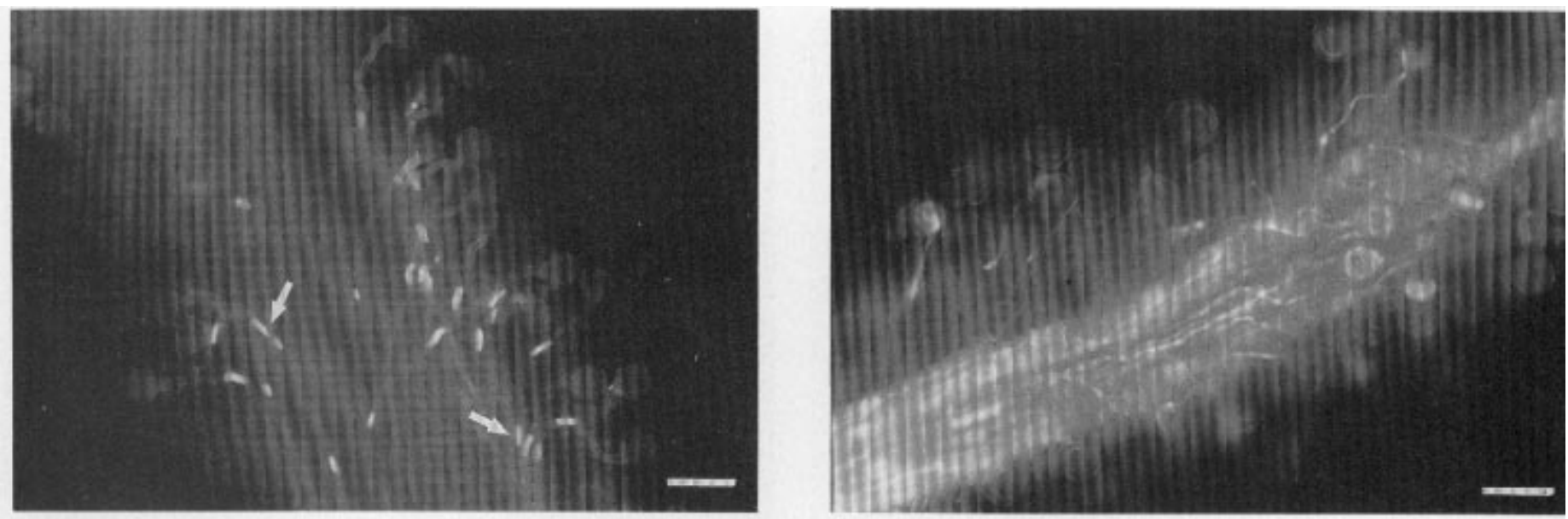

A
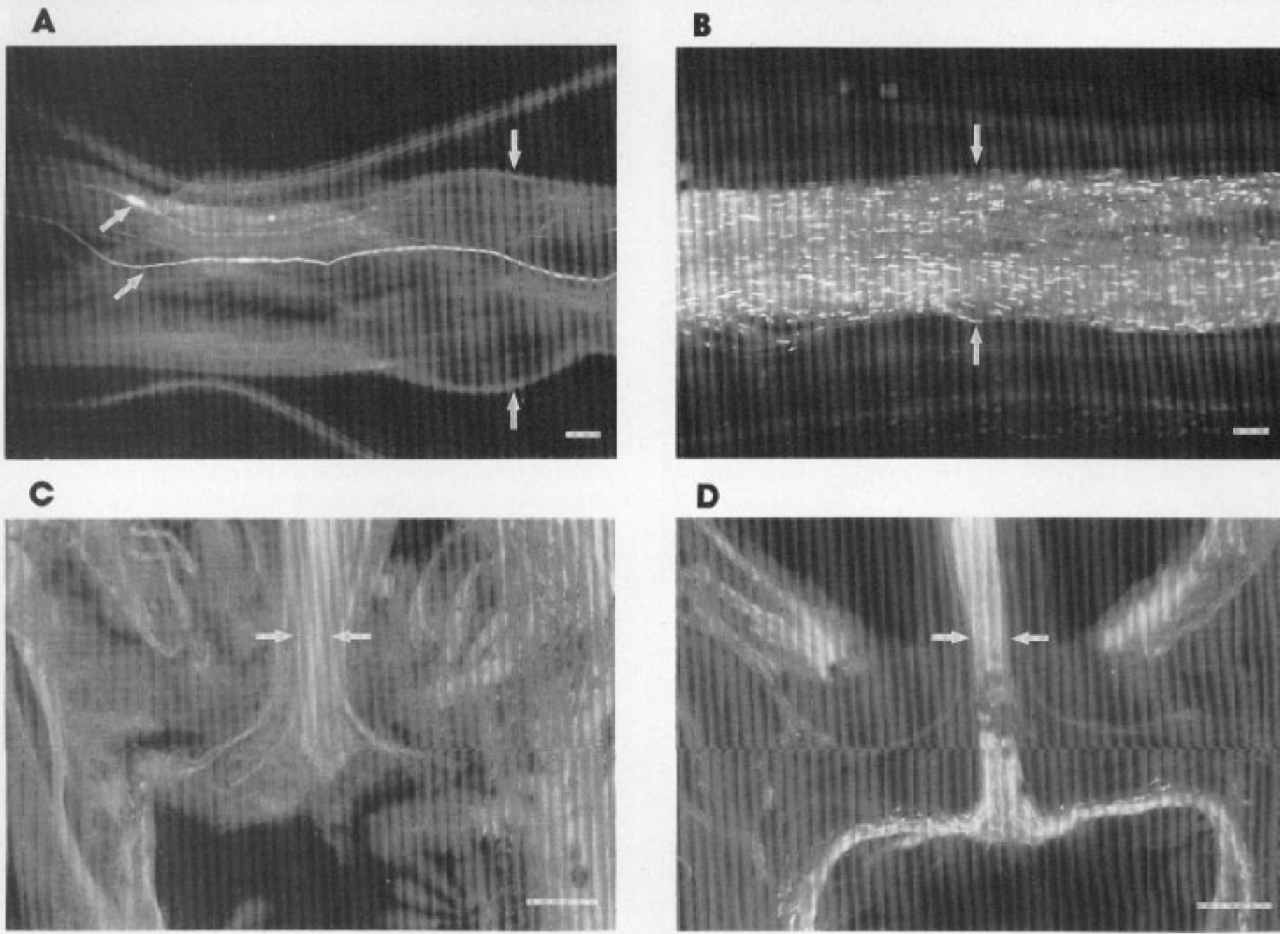

Fig. 1. Pistils of 'Crimson Giant' Easter cactus pollinated with incompatible (self) or compatible ('Evita') pollen. Pistils were stained with decolorized aniline blue and viewed using epifluorescence microscopy. (A) Incompatible pollen tubes in the stigmatic region. Arrows indicate callose plugs in pollen tubes. (B) Compatible pollen tubes in the stigmatic region. (C) Incompatible pollen tubes (indicated by left arrows) in the middle of the style. The stylar conducting tissue is located between the arrows at right. (D) Compatible pollen tubes in the middle of the style. The stylar conducting tissue (indicated by arrows) contains numerous pollen tubes that are distinguished by their fluorescing callose plugs. (E) Lower style and ovary of a self-pollinated pistil. No pollen tubes are present in the stylar conducting tissue (between arrows) or ovary. and (F) Lower style and ovary of a compatibly pollinated pistil. Pollen tubes are visible in the stylar conducting tissue (between arrows) and in the ovary. Bars $=100 \mu \mathrm{m}$ in figs. A through $\mathbf{D}$. Bars $=500 \mu \mathrm{m}$ in $\mathbf{E}$ and $\mathbf{F}$.

self-incompatibility (GSI), i.e., where the incompatibility phenotype of the pollen is determined by the gametophyte, pollen is usually binucleate and pollen tube inhibition occurs in the style or ovary. Species exhibiting sporophytic self-incompatibility (SSI), i.e., where the incompatibility phenotype of the pollen is determined by the sporophyte (maternal parent), have trinucleate pollen 


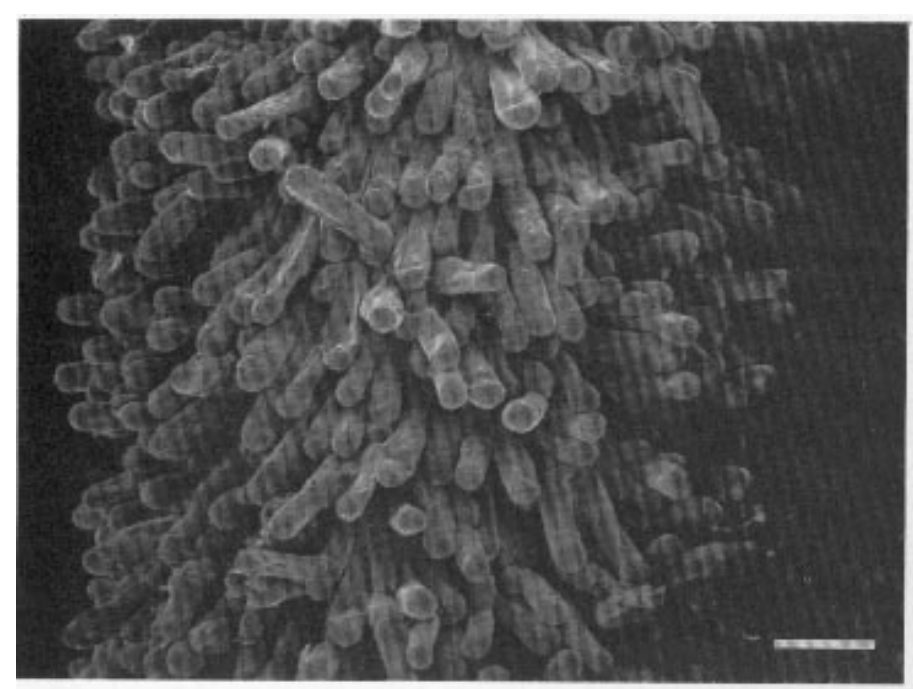

A

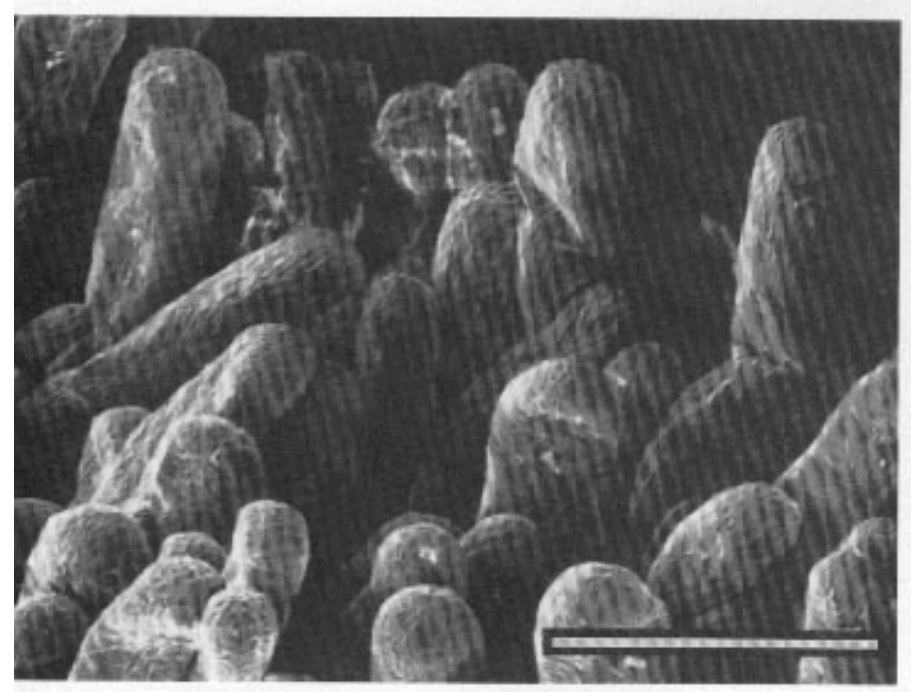

Fig. 2. Scanning electron microscope images of the stigmatic surface for 'Crimson Giant' Easter cactus. (A) Portion of a stylar lobe illustrating the density and arrangement of stigmatic papillae. (B) Detail of stigmatic papillae. Bars $=100 \mu \mathrm{m}$.

and inhibition occurs at the stigmatic surface. Furthermore, taxa with SSI have papillate stigmas with scant stigmatic exudate, whereas taxa with GSI have (in most cases) stigmas with low papillae or a smooth receptive surface, and substantial amounts of stigmatic exudate (Heslop-Harrison et al., 1975). Microscopal examinations of Rhipsalidopsis styles collected between anthesis and senescence revealed that little or no exudate was produced on the stigmatic surface (data not presented). Thus, Easter cactus exhibits several traits typically found in SSI systems: trinucleate pollen, papillate stigmas, and scant stigmatic exudate. However, Easter cactus also exhibits two characteristics associated with GSI systems, i.e., lack of differences between reciprocal crosses (Table 1) and stylar inhibition of pollen tube growth (Fig. 1). Genetical studies are thus needed to resolve whether Easter cactus has a GSI or SSI system.

Expt. 4. Generally, stage of floral development at the time of pollination did not influence fruit or seed yields when 'Crimson Giant' was selfed (Table 2). In contrast, stage of floral development at the time of pollination markedly influenced fruit and seed

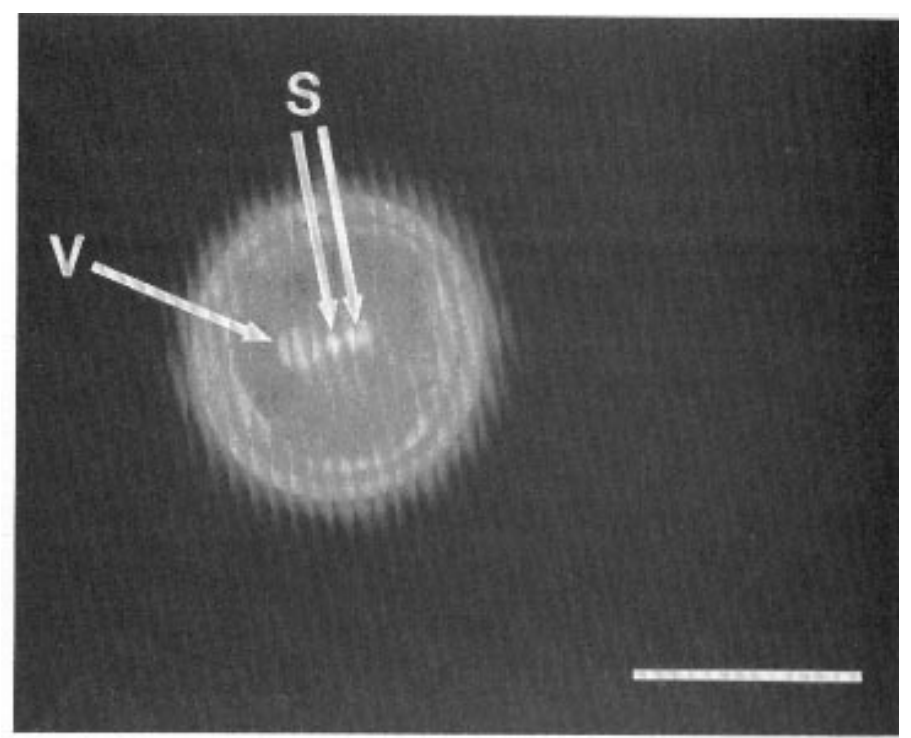

Fig. 3. Ungerminated pollen of 'Crimson Giant' Easter cactus. Fixed pollen was stained with mithramycin and viewed using epifluorescence microscopy. The two sperm nuclei (s) and the vegetative nucleus (v) are evident. Bar $=50 \mu \mathrm{m}$.

yields when 'Crimson Giant' was crossed with compatible pollen (Table 2). For compatible crosses, buds $\leq 2.5 \mathrm{~cm}$ in length did not set fruit, whereas buds $>2.6 \mathrm{~cm}$ in length and open flowers yielded substantial numbers of fruit (Table 2). Fruit and seed yields were maximum when buds $>3.5 \mathrm{~cm}$ in length and open flowers were crossed with compatible pollen.

Bud pollinations have been utilized successfully to overcome GSI and SSI (de Nettancourt, 1977), but were not effective in the current study. With 'Crimson Giant', the maximal yield of self-seed was obtained for buds $>3.5 \mathrm{~cm}$ in length and was 0.2 viable seed per treated flower (Table 2). Buds $\leq 2.5 \mathrm{~cm}$ in length failed to yield fruit when selfed or pollinated with compatible pollen, and these responses can be attributed to pistil immaturity. Buds $>2.6 \mathrm{~cm}$ in length produced seed-bearing fruit when cross-pollinated, but failed to set fruit when self-pollinated. These results demonstrate that stylar SI reactions are fully operative when pistils of Easter cactus attain the capacity to set seed, and the stylar reactions are capable of inhibiting or preventing growth of self-pollen tubes and thus precluding fruit set.

Expt. 5. Application of lanolin only (controls) or BA resulted in $0 \%$ fruit set at 90 DAP (Table 3). In contrast, application of GA or NAAm resulted in $\geq 84 \%$ fruit set at 90 DAP. Ovaries that did not abscise by 90 DAP remained on the plants until harvested at $\approx 160$ DAP. At harvest, ovaries treated with $\mathrm{GA}_{3}$ or NAAm appeared morphologically normal but contained few viable seeds (Table 3 ). NAAm at $0.1 \%(\mathrm{w} / \mathrm{v})$ was the most effective treatment and yielded 0.1 viable seed per treated flower.

Increased yields of self-seed have been obtained in SI taxa by applying growth regulators to pollinated flowers (Emsweller et al., 1960; Matsubara, 1973; de Nettancourt, 1977). GA 3 and NAAm increased fruit set when applied to selfed flowers of 'Crimson Giant', but self-seed was obtained only from fruit treated with NAAm (Table 3). These results indicate that inhibitors of floral abscission are marginally effective in overcoming SI in Rhipsalidopsis.

$\mathrm{GA}_{3}$ is heat-labile and may have decomposed when mixed in hot $(\approx 140 \mathrm{C})$ lanolin (Waring and Phillips, 1978). Thus, promotion of fruit set in 'Crimson Giant' by the $\mathrm{GA}_{3}$-lanolin mixtures may have been due to degradation products of $\mathrm{GA}_{3}$ that can elicit some of the physiological effects of gibberellins (Waring and Phillips, 1978). 
Table 2. Effect of pollen source and floral development stage at time of pollination on percent fruit set, seeds per fruit, percent germination, and viable seeds per flower for 'Crimson Giant' Easter cactus (Expt. 4).

\begin{tabular}{|c|c|c|c|c|c|c|}
\hline $\begin{array}{l}\text { Stage of floral } \\
\text { development }\end{array}$ & $\begin{array}{l}\text { Days to } \\
\text { anthesis } \\
\text { (apx.) }\end{array}$ & $\begin{array}{c}\text { Buds/flowers } \\
\text { pollinated } \\
\text { (no.) }\end{array}$ & $\begin{array}{c}\text { Fruit set } \\
\qquad(\%)^{\mathrm{z}}\end{array}$ & $\begin{array}{l}\text { Seeds per } \\
\text { fruit } \\
(\text { no. })^{\mathrm{y}}\end{array}$ & $\begin{array}{c}\text { Germination } \\
(\%)\end{array}$ & $\begin{array}{l}\text { Viable seeds } \\
\text { per treated } \\
\text { flower } \\
\text { (no.) }\end{array}$ \\
\hline \multicolumn{7}{|c|}{ Self pollinations } \\
\hline $1.0-1.5 \mathrm{~cm}$ buds & $20-26$ & 26 & 0 & --- & --- & --- \\
\hline $1.6-2.0 \mathrm{~cm}$ buds & $15-19$ & 25 & 0 & --- & --- & --- \\
\hline $2.1-2.5 \mathrm{~cm}$ buds & $10-14$ & 25 & 0 & --- & --- & --- \\
\hline $2.6-3.0 \mathrm{~cm}$ buds & $4-9$ & 24 & 0 & --- & --- & --- \\
\hline $3.1-3.5 \mathrm{~cm}$ buds & $2-3$ & 20 & 0 & --- & --- & --- \\
\hline$>3.5 \mathrm{~cm}$ buds & $1-2$ & 35 & 3 & 13 & 46 & 0.2 \\
\hline Open flowers & --- & 23 & 0 & --- & --- & --- \\
\hline \multicolumn{7}{|c|}{ Cross-compatible pollinations } \\
\hline $1.0-1.5 \mathrm{~cm}$ buds & $20-26$ & 26 & 0 & --- & --- & --- \\
\hline $1.6-2.0 \mathrm{~cm}$ buds & $15-19$ & 26 & 0 & --- & --- & --- \\
\hline $2.1-2.5 \mathrm{~cm}$ buds & $10-14$ & 25 & 0 & --- & --- & --- \\
\hline $2.6-3.0 \mathrm{~cm}$ buds & $4-9$ & 25 & 24 & $64 \pm 12$ & 80 & 12.2 \\
\hline $3.1-3.5 \mathrm{~cm}$ buds & $2-3$ & 25 & 80 & $64 \pm 9$ & 84 & 43.0 \\
\hline$>3.5 \mathrm{~cm}$ buds & $1-2$ & 25 & 100 & $117 \pm 8$ & 92 & 107.3 \\
\hline Open flowers & --- & 28 & 100 & $111 \pm 8$ & 93 & 102.8 \\
\hline
\end{tabular}

$\overline{\mathrm{z}}($ No. fruit set $\div$ no. flowers pollinated $) \times 100$. Data collected 90 days after pollinations.

${ }^{\mathrm{y}} \mathrm{Mean} \pm \mathrm{SE}$ (data for fruits with seeds only).

Table 3. Effect of plant growth regulators on percent fruit set, seeds per fruit, percent germination, and viable seeds per flower for self-pollinated flowers of 'Crimson Giant' Easter cactus (Expt. 5).

\begin{tabular}{|c|c|c|c|c|c|}
\hline $\begin{array}{l}\text { Growth } \\
\text { regulator } \\
\text { treatment }^{\mathrm{z}}\end{array}$ & $\begin{array}{l}\text { Fruit } \\
\text { set } \\
(\%)^{y}\end{array}$ & $\begin{array}{c}\text { Fruit } \\
\text { with seeds } \\
(\text { no. })^{\mathrm{x}}\end{array}$ & $\begin{array}{l}\text { Seeds/fruit } \\
\quad(\text { no. })^{\mathrm{w}}\end{array}$ & $\begin{array}{c}\text { Germination } \\
(\%)\end{array}$ & $\begin{array}{l}\text { Viable seeds per } \\
\text { treated flower } \\
\quad \text { (no.) }\end{array}$ \\
\hline Control (lanolin) & 0 & --- & --- & --- & --- \\
\hline $0.1 \% \mathrm{BA}$ & 0 & --- & --- & --- & --- \\
\hline $1.0 \% \mathrm{BA}$ & 0 & --- & --- & --- & --- \\
\hline $0.1 \% \mathrm{GA}_{3}$ & 92 & 1 & 1 & 0 & 0 \\
\hline $1.0 \% \mathrm{GA}_{3}^{3}$ & 84 & 0 & --- & --- & --- \\
\hline $0.1 \%$ NAAm & 100 & 5 & $1 \pm 0$ & 60 & 0.1 \\
\hline $1.0 \%$ NAAm & 100 & 0 & --- & --- & --- \\
\hline
\end{tabular}

$\overline{\mathrm{z}} \mathrm{BA}=$ benzyladenine; $\mathrm{GA}_{3}=$ gibberellic acid; NAAm $=$ naphthaleneacetamide. All growth regulators were applied to the ovary immediately following pollination. Twenty-five flowers pollinated per treatment.

y $($ No. fruit set $\div$ no. flowers pollinated $) \times 100$. Data collected 90 days after pollinations.

${ }^{x}$ Data collected $\approx 160$ days after pollinations.

${ }^{\mathrm{w}}$ Mean \pm SE (data for fruits with seeds only).

Expt. 6. No fruit was set when buds were exposed to $40 \mathrm{C}$ for 0 , 6 , or $48 \mathrm{~h}$ and self-pollinated, regardless of timing of pollination (Table 4). Fruit formation was obtained when buds were exposed to $40 \mathrm{C}$ for $12 \mathrm{hor} 24 \mathrm{~h}$ and were selfed immediately following or 24 $\mathrm{h}$ after incubation. Self-seed yields were greatest when plants were incubated for $12 \mathrm{~h}$ at $40 \mathrm{C}$ and buds were pollinated immediately following incubation. When compatible pollen was used for crosses, seed yields were greatest for buds exposed to $40 \mathrm{C}$ for 0,6 , or $12 \mathrm{~h}$ (Table 4). For compatible crosses, incubation at $40 \mathrm{C}$ for $\geq 24 \mathrm{~h}$ reduced the numbers of viable seed per treated flower compared to incubation for $\leq 12 \mathrm{~h}$.

High temperatures ranging from 32 to $50 \mathrm{C}$ have been reported to overcome SI in several taxa (Johnson, 1971; de Nettancourt, 1977; Ronald and Ascher, 1975). For 'Crimson Giant', yields of self-seed were markedly affected by the duration of heat treatment. When flowers were self-pollinated immediately after or $24 \mathrm{~h}$ after heat treatment, a 0 - or 6-h incubation period did not result in seed formation, whereas a 12- or 24-h incubation period yielded seed (Table 4). These results suggest that a 12- or 24-h exposure to $40 \mathrm{C}$ either decreased or eliminated product(s) involved in SI reactions in the pistil. For compatibly pollinated flowers, a 48-h heat treatment reduced percent fruit set, number of seeds per fruit, and percent seed germination compared to heat treatments lasting for $\leq 12 \mathrm{~h}$ (Table 4). Hence, failure to obtain fruit when flowers were selfed after $48 \mathrm{~h}$ at $40 \mathrm{C}$ was probably due to the deleterious effects of high temperature on female fertility.

Expt. 7. Two zones of AAT activity were observed in PAGE gels (Fig. 4A). Aat-2 was monomorphic in 'Crimson Giant' and all $\mathrm{S}_{1}$ progeny. Aat- 1 was polymorphic, and plants yielded either a single-banded pattern or a three-banded pattern. These results were interpreted as indicating two homodimers and one heterodimer of intermediate mobility, and are consistent with previous studies on AAT (Weeden and Wendel, 1989). The two homodimer bands were labeled $a a$ and $b b$ in order of decreasing 
Table 4. Effect of heat treatment duration, timing of pollination, and pollen source on percent fruit set, seeds per fruit, percent germination, and viable seeds per flower for 'Crimson Giant' Easter cactus (Expt. 6).

\begin{tabular}{|c|c|c|c|c|c|c|}
\hline $\begin{array}{l}\text { Heat treatment } \\
\text { duration } \\
\text { (h) }\end{array}$ & $\begin{array}{l}\text { Timing of } \\
\text { pollination }^{\mathrm{z}}\end{array}$ & $\begin{array}{c}\text { Buds/flowers } \\
\text { pollinated } \\
\text { (no.) }\end{array}$ & $\begin{array}{l}\text { Fruit set } \\
\qquad(\%)^{\mathrm{y}}\end{array}$ & $\begin{array}{l}\text { Seeds per } \\
\text { fruit } \\
(\text { no. })^{\mathrm{x}}\end{array}$ & $\begin{array}{c}\text { Germination } \\
(\%)\end{array}$ & $\begin{array}{c}\text { Viable seeds/ } \\
\text { treated } \\
\text { flower } \\
\text { (no.) }\end{array}$ \\
\hline \multicolumn{7}{|c|}{ Self pollinations } \\
\hline 0 (Control) & --- & 20 & 0 & --- & --- & --- \\
\hline 6 & -0 & 20 & 0 & --- & --- & --- \\
\hline 6 & +0 & 20 & 0 & --- & --- & --- \\
\hline 6 & +24 & 22 & 0 & --- & --- & --- \\
\hline 12 & -0 & 20 & 0 & --- & --- & --- \\
\hline 12 & +0 & 20 & 20 & $41 \pm 12$ & 78 & 7.2 \\
\hline 12 & +24 & 27 & 15 & $18 \pm 5$ & 79 & 2.0 \\
\hline 24 & -0 & 20 & 0 & --- & --- & --- \\
\hline 24 & +0 & 21 & 10 & $18 \pm 2$ & 74 & 1.2 \\
\hline 24 & +24 & 21 & 5 & 7 & 71 & 0.2 \\
\hline 48 & -0 & 22 & 0 & --- & --- & --- \\
\hline 48 & +0 & 19 & 0 & --- & --- & --- \\
\hline 48 & +24 & 18 & 0 & --- & --- & --- \\
\hline \multicolumn{7}{|c|}{ Compatible cross-pollinations } \\
\hline 0 (Control) & --- & 20 & 100 & $113 \pm 9$ & 86 & 97.6 \\
\hline 6 & +0 & 21 & 100 & $144 \pm 6$ & 94 & 135.0 \\
\hline 12 & +0 & 24 & 96 & $112 \pm 10$ & 88 & 94.9 \\
\hline 24 & +0 & 20 & 70 & $85 \pm 9$ & 84 & 50.1 \\
\hline 48 & +0 & 22 & 23 & $10 \pm 2$ & 65 & 1.4 \\
\hline
\end{tabular}

${ }^{\mathrm{z} N o}$. of hours before (-) or after (+) heat treatments.

$\mathrm{y}($ No. fruit set $\div$ no. flowers pollinated $) \times 100$. Data collected 90 days after pollinations.

${ }^{\mathrm{x}}$ Mean \pm SE (data for fruits with seeds only).

relative mobility (Fig. 4A). 'Crimson Giant' was heterozygous $(a b)$ at Aat-1. For the $\mathrm{S}_{1}$ progeny, the observed ratio $(4 a a: 37 a b$ $: 34 b b)$ deviated significantly from the expected $1: 2: 1(a a: a b: b b)$ ratio $\left(\chi^{2}=21.49, P<0.001\right)$.

Two zones of PGM activity were observed in PAGE gels (Fig. 4B). Pgm- 1 was monomorphic for all $73 \mathrm{~S}_{1}$ progeny and 'Crimson Giant', whereas Pgm-2 was polymorphic and consisted of two single-banded patterns and one two-banded pattern. Navot and Zamir (1986) and Weeden and Gottlieb (1980) have shown that PGM is a monomer, and the current results are consistent with a monomeric enzyme. The two Pgm-2 bands were labeled $a$ and $b$ in order of decreasing relative mobility (Fig. 4B). 'Crimson Giant' was heterozygous $(a b)$ for $P g m$-2. For the $\mathrm{S}_{1}$ family, the observed ratio (25aa:37ab:11bb) did not deviate significantly from the expected 1:2:1 $(a a: a b: b b)$ ratio $\left(\chi^{2}=5.38,0.10>P>0.05\right)$, and these results are consistent with a single codominant nuclear gene.

Aberrant segregation ratios of isozymes have been reported in several taxa and have been attributed to linkage between isozyme loci and other genes subject to pre- or postzygotic selection (Manganaris and Alston, 1987; Wendel and Parks, 1984; Zamir and Tadmor, 1986). Aberrant segregation at Aat-1 in 'Crimson Giant' may have been due to linkage between isozyme loci and the SI $(S)$ locus, as reported for Malus pumila Mill. (Manganaris and Alston, 1987) and Camellia japonica L. (Wendel and Parks, 1984). Segregation distortion at Aat- 1 could also result from linkage between isozyme loci and genes conferring temperature sensitivity, with heat exposure selectively eliminating certain genotypes of ovules or promoting differential growth rates for incompatible pollen tubes. Alternatively, postzygotic mechanisms may be responsible for distorted segregation at Aat- 1 . Forced selfing of a normally outbred species would be expected to result in some weak or inviable $S_{1}$ progeny, thus leading to the attrition of some genotypes before PAGE analysis. In Expt. 6, seed set and seed germination were notably lower for selfed flowers than for outcrossed flowers (Table 4), suggesting that postzygotic selection may have occurred in the $S_{1}$ population.

Despite the presence of segregation distortion, the recovery of homozygotes in the $\mathrm{S}_{1}$ progeny of 'Crimson Giant' confirms that heat treatments were successful in overcoming SI in Easter cactus. Furthermore, the maximum yields of viable seed per treated flower were considerably greater for heat treatments than for bud pollinations or growth regulator treatments (Tables 2, 3, and 4). Utilization of $S_{1}$ progeny in breeding programs may extend the flower color range and lead to a greater diversity in other plant characteristics than currently exists in cultivated Easter cactus. Genetic studies are presently being conducted to ascertain whether the incompatibility phenotype of the pollen is determined by the gametophyte or sporophyte in the Cactaceae.

\section{Literature Cited}

Ascher, P.D. 1975. Self-incompatibility systems in floriculture crops. Acta Hort. 63:205-215.

Boyle, T.H. 1991. Temperature and photoperiodic regulation of flowering in 'Crimson Giant' Easter cactus. J. Amer. Soc. Hort. Sci. 116:618-622.

Boyle, T.H. and D.P. Stimart. 1989. A grower's guide to commercial production of Easter cactus. GrowerTalks 53:50-52.

Breckenridge, F.G. and J.M. Miller. 1982. Pollination biology, distribution, and chemotaxonomy of the Echinocereus enneacanthus complex. Systematic Bot. 7:365-378.

Brewbaker, J.L. 1957. Pollen cytology and self-incompatibility systems in plants. J. Hered. 48:271-277.

Brewbaker, J.L. 1959. Biology of the angiosperm pollen grain. Ind. J. Genet. Plant Breeding 19:217-277.

Coleman, A.W. and L.J. Goff. 1985. Applications of fluorochromes to pollen biology. I. Mithramycin and 4',6-diamidino-2-phenylindole 


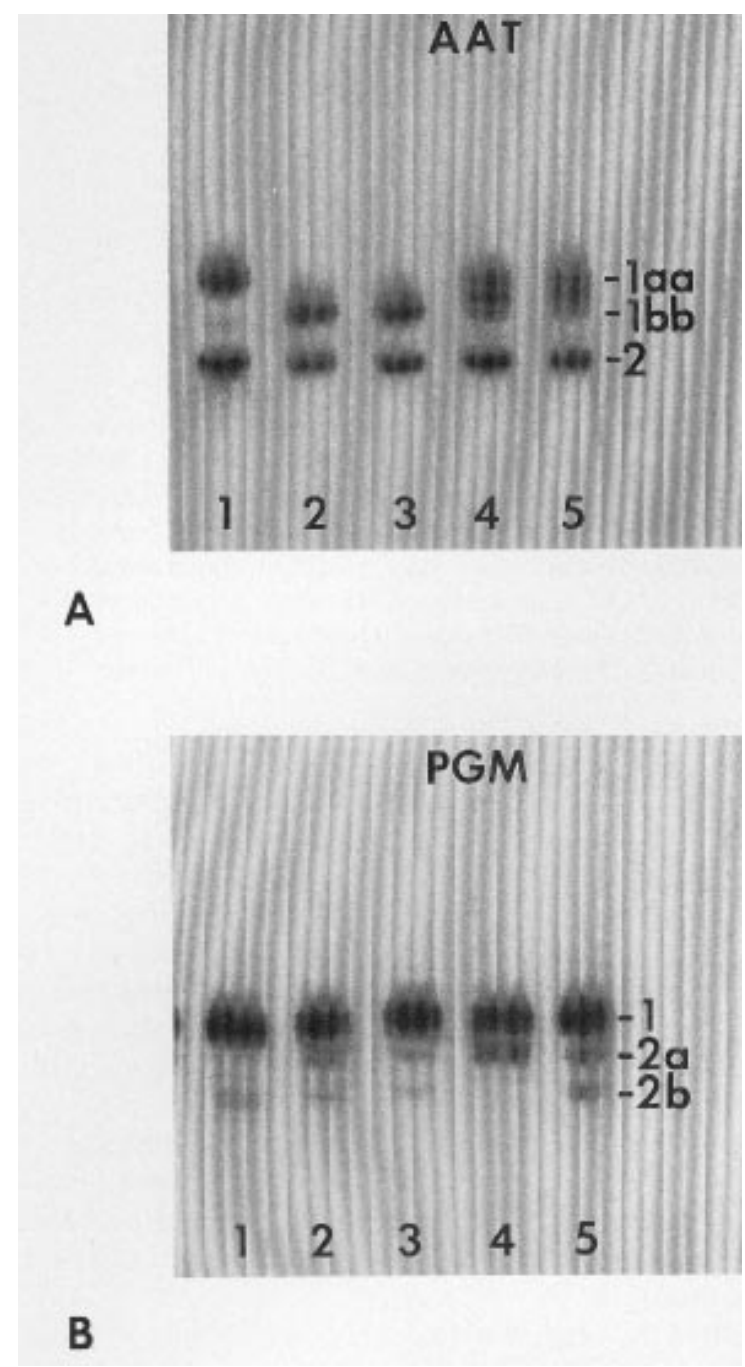

Fig. 4. Aspartate aminotransferase (AAT) and phosphoglucomutase (PGM) zymograms for 'Crimson Giant' Easter cactus (lane 5) and four $S_{1}$ progeny (lanes 1-4). The anode is towards the top of the figure. (A) AAT. and (B) PGM.

(DAPI) as vital stains and for quantitation of nuclear DNA. Stain Tech. 60:145-154.

East, E.M. 1940. The distribution of self-sterility in flowering plants. Proc. Amer. Philosophical Soc. 82:449-518.

Emsweller, S.L. 1954. Plant regulators and plant breeding, p. 161-169. In: H.B. Tukey (ed.). Plant regulators in agriculture. Wiley, New York.

Emsweller, S.L., J. Uhring, and N.W. Stuart. 1960. The roles of naphthalene acetamide and potassium gibberellate in overcoming self-incompatibility in Lilium. Proc. Amer. Soc. Hort. Sci. 75:720-725.

Fryxell, P.A. 1957. Mode of reproduction of higher plants. Bot. Rev. 23:135-233.

Ganders, F.R. 1976. Self-incompatibility in the Cactaceae. Cactus Succulent J. Great Britain 38:39-40.

Heslop-Harrison, J., Y. Heslop-Harrison, and J. Barber. 1975. The stigma surface in incompatibility responses. Proc. Royal Soc. London Ser. B 188:287-297.

Johnson, A.G. 1971. Factors affecting the degree of self-incompatiility in inbred lines of brussels sprouts. Euphytica 20:561-573.

Liberty Hyde Bailey Hortorium. 1976. Hortus third. A concise dictionary of plants cultivated in the United States and Canada. Macmillan, New York.

Manganaris, A.G. and F.H. Alston. 1987. Inheritance and linkage relationships of glutamate oxaloacetate transaminase isoenzymes in apple. Theoretical and Applied Genet. 74:154-161.

Martin, F.W. 1959. Staining and observing pollen tubes in the style by means of fluorescence. Stain Technol. 34:125-128.

Matsubara, S. 1973. Overcoming self-incompatibility by cytokinins-treatment on Lilium longiflorum. Bot. Mag. (Tokyo) 86:43-45.

Moran, R. 1953. Taxonomic studies in the Cactaceae, I-II. Gentes Herbarum 8(4):316-345.

Navot, N. and D. Zamir. 1986. Linkage relationships of 19 protein coding genes in watermelon. Theoretical and Applied Genet. 72:274-278.

de Nettancourt, D. 1977. Incompatibility in angiosperms. Springer, Berlin.

Neumann, M. 1935. Die Entwicklung des Pollens, der Samenanlage und des Embryosackes von Pereskia amapola var. argentina. Österreich Bot. Zeitschrift 84:1-30.

Ronald, W.G. and P.D. Ascher. 1975. Effects of high temperature treatments on seed yield and self incompatibility in chrysanthemum. Euphytica 24:317-322.

Ross, R. 1981. Chromosome counts, cytology, and reproduction in the Cactaceae. Amer. J. Bot. 68:463-470.

Taylor, N.P. 1976. More self-incompatibility in cacti. Cactus Succulent J. Great Britain 38:67.

Waring, P.F. and I.D.J. Phillips. 1978. The control of growth and differentiation in plants, p. 60. 2nd ed. Pergamon, Oxford, England.

Weeden, N.F. and L.D. Gottlieb. 1980. The genetics of chloroplast enzymes. J. Hered. 71:392-396.

Weeden, N.F. and J.F. Wendel. 1989. Genetics of plant isozymes, p. 4672. In: D.E. Soltis and P.S. Soltis (eds.). Isozymes in plant biology. Dioscorides, Portland, Ore.

Wendel, J.F. and C.R. Parks. 1984. Distorted segregation and linkage of alcohol dehydrogenase genes in Camellia japonica L. (Theaceae). Biochem. Genet. 22:739-748.

Wendel, J.F. and N.F. Weeden. 1989. Visualization and interpretation of plant isozymes, p. 5-45. In: D.E. Soltis and P.S. Soltis (eds.). Isozymes in plant biology. Dioscorides, Portland, Ore.

Zamir, D. and Y. Tadmor. 1986. Unequal segregation of nuclear genes in plants. Bot. Gaz. 147:355-358.

Zimmer, K. 1980. Untersuchungen über den Einflu $\beta$ die Temperatur auf die Keimung von Kakteensaatgut XI. Keimung einiger Epiphyllinae und Rhipsalidinae. Gartenbauwissenschaft 45:205-207. 